DOI: 10.22363/2312-8674-2018-17-2-234-247

\title{
IN SEARCH OF SELF-IDENTITY: JEWS IN THE CONTEXT OF THE RUSSIAN CULTURE
}

\author{
Alla Meyerovich, Irena Vladimirsky \\ Achva Academic College \\ POB Shikmim, Beer Tuvia, 79800, Israel \\ irena@achva.ac.il
}

The article focuses on the formation of cultural and social self-identification of an ethnic minority within a multicultural society as well as on the establishment and functioning of a state as a conglomerate of various ethnic constituents. Nowadays this subject is vital, as many European countries have found themselves in a situation under which they have to host numerous migrants and assimilate them. It should be emphasized that minorities, their way of life, language they speak and education their children get always reflect general trends existing in the society as well as the official policy towards minorities, prejudices or lack of prejudices in the society. In this study, the authors investigate the possibility of integration and assimilation as well as the historical and social conditions necessary for assimilation in a society and for understanding its importance within a community. Integration means acceptance of a new culture, language and traditions, better understanding of a new religion and ethnic characteristics in order to be a part of a hosting society. It is the history of the Jewish community in Russia, which is analyzed in the article. Since the aim of the present study is the understanding of self-identification, i.e. personal self-perception of an individual in the society, of great value are the memoirs as sources of information and their textual analysis. The objectives of the research are to study the main aspects of social life: religion, education, language. Based on the exact results, the conclusion may be regarded as universal and generally applicable when forming ways of integration of minorities into a single public space.

Keywords: Jews of the Russian Empire, ethnic minority, multicultural state, national policy, self-identification

\section{Introduction}

This study asks to analyze various sides of life in a multicultural society, including language, history of people, religion inside and outside a community (tolerance/lack of tolerance), attitude towards strangers/newcomers, traditional education, traditional gender attitudes as factors preserving/modifying personal self-identity. 
The historical background is of specific interest for this study as it helps clarify the situation. Thus, concentrating on history, religion, education and language seem absolutely logically approved within this study of Jewish self-identification in the Russian Empire.

Sources and literature on the subject are numerous and characterized by their variety, tendencies and approaches. The sources and literature could be divided into four unequal groups of different character. The first group of sources deals with various aspects of the history of the Jewish issue in Russia ${ }^{1}$ and attempts to solve it through numerous regulations and decisions. The second group of sources represents the majority's vision of the Jews (mainly by Russian population) impression of Jews through the Russian eyes ${ }^{2}$ and based mostly on personal interaction, stereotypes, religious and social comparison. The most interesting and unique group of sources is the memoirs of the Jews ${ }^{3}$ who made an

${ }^{1}$ I.M. Aronson, "Russian Commissions on the Jewish Question in the 1880's.," East European Quarterly 14, no. 1 (1980): 59-74; S.M. Dubnov, Noveishaiia istoriia evreiskogo naroda. 1789-1881 (Moscow-Ierusalim: Mosty kultury, and Gershaim Publ., 2002); Yuliy I. Gessen, "Popytka emansipatsii evreev v Rossii," Perezhitoe, no. 1 (1909): 144-163; N.D. Gradovskii, Otnoshenie $k$ evreyam $v$ devnei i sovremennoi Rusi: Motivy istorikonacional'nye. S tochki zreniia russko-pravoslavnoi (St. Petersburg: [S.n.], 1891); Lev A. Kassil, Konduit i Shvambraniia (Moscow: Detskaiia literature Publ., 1960); Nikolay M. Karamzin, Pis'ma russkogo puteshestvennika (Moscow: Pravda Publ., 1980); M. Krutikov, "Pushkin v Vil'ne: Russkaiia Literatura i Evreiskaiia Intelligentsiia," in Leo Philologiae. (Moscow, [S.n.], 2016), 128-163; D.L. Mordovtsev, Vol. 1 of Polnoe sobranie istoricheskih romanov, povestei rasskazov. S kritiko-biograficheskim ocherkom (Moscow: [S.n.], 1902); I.G. Orshanski, Evrei v Rossii: ocherki ekonomicheskogo i obshchestvennogo byta russkikh evreev (St. Petersburg: Print of Bakst, 1877); S.V. Pozner, Evrei v obshchei shkole:(k istorii zakonodatel'stva i pravitel'stvennoi politiki v oblasti evereiskago voprosa) (St. Peterburg: Razum Publ., 1914); Y. Slutsky, Ha-'Itonut ha-Yehudit-Rusit ba-me'ah ha-tesha-esreh [Jewish Russian-language press in the $19^{\text {th }}$ century](Jerusalem: Publ. of Bialik institute, 1970).

2 M.M. Gel'fond, “Tvorcheskaiia istoriia avtobiograficheskoi trilogii A.Ya. Brushtein 'Doroga ukhodit vdal," Novyi Filologicheskii Vestnik 28, no. 1 (2014): 81-90; Yuliy I. Gessen, Istoriâ Evreiskogo naroda v Rossii. 2 vols. (Leningrad, Printing house K.-O. Leningrad Gubprofso Council, 1925-1927); H. Grets, "Ot nachala Mendel'sonovskoi epohi do noveishego vremeni (1750-1848)," in Istoriia evreev ot drevneishih vremen do nastoyashchego (Odessa: Print Hous of Sherman, 1900); V. Karasik, Eveiskaia pressa na russkom yazyke: bibliograficheskii spravochnik (Moscow: N.I. Krotov Publ., 1992); M. Krutikov, "Pushkin v Vil'ne: Russkaiya Literatura i Evreiskaiia Intelligentsiia"; Yuriy M. Lotman, Struktura khudozhestvennogo teksta. Semioticheskie issledovaniya po teorii iskusstva (Moscowa: Iskusstvo Publ., 1970); S.M. Lowenstein, "Governmental Jewish policies in early nineteenth century Germany and Russia: A comparison," Jewish Social Studies 46, no. 3/4 (1984): 303-320; N.G. Pomyalovskii, Ocherki bursy (Moscow: Prospekt Publ., 2014); S.V. Pozner, Evrei v obshchei shkole.

${ }^{3}$ I.M. Aronson, "Russian Commissions on the Jewish Question in the 1880's."; S.M. Dubnov, Kniga zhizni. Vospominaniia i razmyshleniia: materialy dlya istorii moego vremeni (Moscow: Evreiskogo universiteta Publ., 1998; Leonid Grossman, Ispoved' odnogo ev- 
attempt to consciously identify themselves as Russian empire subjects. These Jews shared a strong desire for integration that due to the situation in the country had lots of obstacles to overcome, the obstacles resulted just from the fact of their Jewishness. The fourth group of sources shows the search for self-identification through the dominant element of the Russian culture, the Russian language $^{4}$. Jewish journals very quickly in addition to Yiddish and Hebrew started being published in Russian, which became their visual sign of belonging to the dominant Russian culture. Their analysis showed the stages of integration, its problems, obstacles and recommendations (both practical and theoretical).

Jewish community existence in Russian empire shares some general characteristics of minorities within multicultural societies and presents some unique features as well. The long $19^{\text {th }}$ century brought considerable changes into traditional Jewish communities that began their integration into the Russian economy. Timber and grain trade, railways and banking replaced traditional and selling of alcohol. The history of minorities demonstrates two major possibilities: migration and occupation. Migration brought the Jewish people to Europe and occupation made them become citizens of Russia. Such magazines of the second half of the $19^{\text {th }}$ century as "Jewish Antiquity" (In Russian: "Evreiskaiia Starina"), "Jewish library" (In Russian: "Evreiskaiia Biblioteka"), "Russian Jew" (In Russian: "Russkii Evrei") and "Dawn" (In Russian: "Rassvet"), the activity of the "Society on spreading of Education among the Jews" (In Russian: "Obshchestvo po rasprostraneniiyu prosveshcheniia sredi evreev") demonstrated the inner processes within the Jewish community andstarting points of its in-

reiia (Moscow-Leningrad: Svetoch Print, 1924; R.M. Kantor, "Razgrom evreiskoi intelligentsia," Evreiskaia letopis, no. 2 (1924): 87-95; J. Klier, Russia gathers her Jews: the origins of the "Jewish question" in Russia, 1772-1825 (Northern Illinois University Press, 2011); L.O. Levanda, Tipy i siluyety: iz vospominanii zhkol'nika kontsa 40-h godov (St. Petersburg: Voshod Publ., 1881); Samuil Marshak, V nachale zhizni: stranitsy vospominanii (Moscow: Sovetskii pisatel' Publ., 1961); M. Morgulis, "Iz moih vospominanii," Voskhod, no. 2; no. 2, 1895, p. 110-116; no. 5/6, 1896, p. 177-181; no. 6/7, 1897, p. 65-84.

${ }^{4}$ Josef Fraenkel, The Jewish Press of the World (London: Cultural Department of the World Jewish Congress, 1956); M.M. Gel'fond, "Tvorcheskaiia istoriia avtobiograficheskoi trilogii A.Ya. Brushtein 'Doroga ukhodit vdal' "; Leonid Grossman, Ispoved' odnogo evreiia; Lev N. Gumilev, Otkrytie Khazarii (Moscow: AST Publ., 2014); S.S. Harcave, "The Jewish question in the first Russian Duma," Jewish Social Studies, no. 6 (1944): 55-176; U.G. Ivask, Evreiskaia pechat'v Rossii. Materialy dlya istorii evreiskoi zhurnalistiki. Issue 1 (Tallin, 1935); D.L. Mordovtsev, Irod: istoricheskii roman (Moscow: P.P. Soikin Publ., 1914); A. Orbach, New Voices of Russian Jewry: a study of the Russia-Jewish press of Odessa in the era of the Great reforms, 1860-1871 (Leiden: Brill, 1980); M. Perlmann, "Notes on 'Rassvet' 1860-1861," Proceedings of the American Academy for Jewish Research 33 (1965): 21-50; Richard Pipes, "Catherine II and the Jews: The origins of the pale of settlement," East European Jewish Affairs 5, no. 2 (1975): 3-20. 
volvement in Russian culture, economy and political life. Personal memoirs reflect authentic feelings and intentions, attitude to Russian language and culture, attitude to community language and culture and thus give closer view of the situation.

The aim of the study is to point out various tendencies of life in a multicultural society, including, together with the language, history of people, religion inside and outside (tolerance/lack of tolerance), attitude towards strangers/newcomers, traditional education, traditional gender relations as factors of the nation's existence. The historical background is of specific interest for this study as it helps clarify the situation. Thus, concentrating on history, religion, education and language seem absolutely logically approved within this study of Jewish self-identification in the Russian Empire.

One of the objectives of this study is not to examine linguistic determinism theories, but to apply the ideas in the studies of mentality shift in new bilinguals as representatives of minorities in a multicultural society. The fact of existence of such a phenomenon as self-identification of representatives of a specific cultural and ethnic community is relevant in today's world, in which there are practically no homogeneous (monolingual or monocultural) states and societies.

Another objective deals with religion and a majority tradition to accept/ reject representatives of other confessions. Judaic religion (before the end of the $18^{\text {th }}$ century) was represented in Russia by some scientists and merchants only and in those cases triggered no special interest.

Education, the factor that very often (together with family, of course) predetermines one's self-identity (at least at the first stages of personality development) will be a matter of the analysis in this study as well and thus could be regarded as important subject for a deep and broad research.

\section{Jews of the Russian Empire after the third partition of Poland}

History of Jews of the Russian Empire began with the three partitions of Poland in 1772, 1793 and 1795. In a short period of time about three million of new citizens were incorporated into the Empire and became its new subjects. Were they so wanted there? Was this incorporation necessary for the Russian empire, were the Jewish citizens welcomed newcomers? For a long time Russia had been well-known for its ethnic and religious diversity and high degree of tolerance, but the Jewish experience was absolutely differed from other new citizens' stories. The Jewish people practically hadn't assimilated in Western European societies, and the reasons had been both social, cultural and religious, 
both inside Jewish communities and outside; the tendency remained the same when they became a part of the Russian Empire population. As the new Russian subjects, Jews populated mostly rural areas and small towns, earning their living by shop keeping, peddling, artisanship and a variety of trades connected to alcoholic beverages 5 . A Jew (also known as zhid or evrei) became a kind of a legal category, but no successful attempt was made to define who objectively a Jew was, to establish exact characteristic that should necessarily be attributed to a member of the Jewish community ${ }^{6}$.

Jewish community existence in Russian empire shares some general characteristics of minorities within multicultural societies and presents some unique features as well. The long $19^{\text {th }}$ century brought considerable changes in traditional Jewish communities that began their integration into the Russian economy. Timber and grain trade, railways and banking replaced traditional production and selling of alcohol. The history of minorities demonstrates two major possibilities: migration and occupation. Migration brought the Jewish people to Europe and occupation made them become citizens of Russia ${ }^{7}$.

The period when the Jews found themselves as Russian empire subjects was a period of social and economic revolutions, borders opened for a flow of peoples, and exchange of cultural concepts and ideas between West and East became a fact of national and international social life. The new generation of the Jewish people was formed, the generation that realized the possibilities of the 'open society' and advantages of integration. Jews as visitors had been known in Russia long before the $18^{\text {th }}$ century, Judaism had had an important place as one of the religious choices of consolidation of Russian state ${ }^{8}$. Jews deserved the same attitude as the other foreigners who frequently visited Russia, but never became a threat or unwanted element. A new situation when a huge quantity of the Jewish people became a part of Russian empire required new official attitude and initiated new social attitude to the phenomenon as it already manifested the case of ethnic minority/majority relations. When the Jews became a mass

${ }^{5}$ I.G. Orshanski, Evrei v Rossii: ocherki ekonomicheskogo i obshchestvennogo byta russkikh evreev (St. Petersburg: Bakst Publ., 1877), 3-8.

${ }^{6}$ John Doyle Klier, J. Russia gathers her Jews: the origins of the "Jewish question» in Russia, 1772-1825 (Dekalb: Northern Illinois University Press, 2011), 505-506.

7 John Doyle Klier, "The Ambiguous Legal Status of Russian Jewry in the Reign of Catherine II," Slavic Review 35, no. 3 (1976): 504-517.

${ }^{8}$ H. Grets, Ot nachala Mendel'sonovskoi epohi do noveishego vremeni (1750-1848), vol. 12, of Istoriia evreev ot drevneishih vremen do nastoyashchego (Odessa: Publ. of Sherman, 1900), 542-563; I.G. Orshanski, Evrei v Rossii: ocherki ekonomicheskogo i obshchestvennogo byta russkikh evreev (St. Petersburg: Print of Bakst, 1877), 240-241. 
phenomenon and a part of everyday reality the attitude towards them changed from romanticizing them to the realistic approaches such as possible real assimilation on the one hand and - on the other hand - ridiculing them and proclaiming them as unwelcome elements that could be easily accused of all the hardships and turned to object for humiliation and extinction.

As an ethnic/cultural minority, the Jewish community had their own religion different from Russian Orthodox Christianity, its own customs and traditions 9 . Jewish self-identity had always been based on faith that let the Jewish people survive. In Russia traditionally laws were more tolerant to different religions than in many other European countries. Two main factors contributed to the situation. One of them was lack of fanatic tendencies and human attitude towards representatives of other religious confessions, including the Jewish one, on the side of the herds of the Russian Orthodox church. The other one was the policy towards keeping all the citizens inside the country rather than expelling non-Christian religions communities from it. So after the final partition of Poland in 1795, the new governor-general of Byelorussian province Zakhar Chernyshev, promised the Jews respect as official attitude to their Jewish community (kahal), freedom of religion (religious practices), confirmation of their existing property rights as well as confirmation a validity of their own courts and tribunals ${ }^{10}$. At the end of the $18^{\text {th }}$ - the beginning of the $19^{\text {th }}$ centuries, religious limitations did not exist in relation to the Jewish communities, the Jewish self-identification based on faith remained as a stabile factor.

\section{Jewish education and views on its transformation}

Education and language factors are strongly interrelated and in general reflect the social status of a minority. Alexander I tried to set up educational institutions for Jewish children, but teaching there had to be conducted in Russian. In 1802 Alexander I established a special Committee under the chairmanship of G.R. Derzhavin with a purpose to find the arrangement for the new Russian empire' subjects. Derzhavin visited the new Russian provinces and was strongly impressed by the poverty and lack of necessary human conditions, poor communications and strong influence of the Jewish community authorities in strict regulation of community life. Derzhavin suggested that the Jews be compelled to be working in honest and useful crafts and thus to undergo moral self-improve-

\footnotetext{
${ }^{9}$ S.M. Dubnov, Noveishaiia istoriia evreiskogo naroda. 1789-1881, 146-179.

${ }^{10}$ Ibid. P. 180-186; Nikolay M. Karamzin, Pis'ma russkogo puteshestvennika, 505-509.
} 
ment similar to German Jews ${ }^{11}$. His recommendation was based on a foreign experience which hardly could be applied in Russia because of the numerous peculiarities (vast territory, density and variety of population, economy, political structure, etc.). Alexander I hoped that the emancipation of Jews will accelerate the conversion of the Jews to Christianity. The work of the Committee resulted in the new Provision on Jews that defined its goal as caring about the benefits of the indigenous inhabitants of the Russian empire. With regard to education, the Provision allowed the Jews to study in all schools, to open their own schools with compulsory teaching of one of the European languages (Russian, German or Polish). The requirement of knowledge of European languages was set for all government officials. As a result of the Provision a Decree on the establishment of a number of Jewish elementary schools was issued. The Decree establishes the need for teaching in these schools only in Russian and that can explain the fact why the schools were unpopular among the Jews ${ }^{12}$.

The notion of education includes two basic constituents: content and form of education (types of institutions, methods and disciplines) and language of education.

The Jewish community of Russia at the end of the $18^{\text {th }}$ - the beginning of the $19^{\text {th }}$ centuries had its own traditional educational institutions. Traditionally for centuries rabbis (community heads) had been teachers themselves or been responsible for appointment of community teachers (melameds) who had taught Jewish boys at schools attached to synagogues (heder); the tradition remained in Russia as well. The Jewish boys were taught Torah with its various interpretations, Hebrew (the sacred language of Torah and praying), reading and writing in Yiddish (everyday communication language). Two consequences of such education could not but manifest themselves: the students had strong personal Jewish self-identity and practically knew nothing about the world outside the Jewish community, doesn't matter whether it was Polish or Russian world. They could communicate with the local population in Polish or Russian only in exceptional cases, when it was business or administrative requirement. Officially established schools for Jewish children were unpopular and education in Russian was not welcomed within the Jewish community and even deserved hostility on the side of the community Rabbis.

${ }^{11}$ Richard Pipes, "Catherine II and the Jews: The origins of the pale of settlement," 4-9; A. Springer, "Gavriil Derzhavin's Jewish Reform Project of 1800," Canadian-American Slavic Studies 10, no. 1 (1976): 10-18.

${ }^{12}$ Yuliy I. Gessen, Istoriâ Evreiskogo naroda v Rossii, 272-311; Yuliy I. Gessen, "Popytka emansipatsii evreev v Rossii," 144-163. 


\section{Reforms in Jewish education during the reigh of Nicolas I}

Policy towards the Jews completely changed during the reign of Nicholas I. The regime of Nicholas I was determined to break down systematically the foundations of the Jewish community, to limit its autonomy and it pushed forward the idea of forced conversion to Russian Orthodox Christianity. The Decree of November 1843 ordered the expulsion of all Jews from their homes within fifty versts from the Russian western border. In 1844 another Decree officially abolished the residual of the Jewish community (kahal); institutions of Jewish traditional education (heder and yeshiva) became objects to state supervision. The decree of 1847 declared the foundation of a network of public schools and seminaries especially set aside for the Jews. Russian Jewry had no choice but choose a policy of passive resistance to the provisions of the Decree ${ }^{13}$. The only fixed and consistent aim of the government was to ensure that the Jews like all the other subjects supplied in full the fixed quota of the community obligations, i.e. to deliver both military recruits and different taxes. The Cantonist system (Jewish recruits) brought to army service approximately fifty thousand children; some of them died out of cold, thirst and neglect in vast numbers. It is rather hard not to disagree with the statement that that policy was directed not to conversion to Orthodox Christianity, but to the enlightenment of the Jewish youth. According to the idea of minister of education count S. Uvarov, state policy cared about the greater involvement of Jews in the social life of Russia. Many parents, who belonged to the Jewish community middle class, decided to send their children to new public schools and seminaries. By 1855 more than 2,500 Jewish children attended public schools and more than five hundred students were enrolled in two Rabbinical seminaries in Vilna and Zhitomir. Among the first generation of graduates were L. Levanda, L. Pinsker and N. Bakst ${ }^{14}$.

In the 1840s' little attention was paid to traditional Jewish education and the only known type of a school was chosen as a model for Jewish educational institutions: seminaries, educational institutions for Russian low class learners. Gymnasiums and Lyceums were only for the children from the high society or well-established families. Seminaries were schools for the children of the Russian clergy, usually free of charge. Orphans and children from needy families were paid minimal scholarship if they promised to accomplish the education.

${ }^{13}$ S.M. Dubnov, Noveishaiia istoriia evreiskogo naroda. 1789-1881, 156-157; S.V. Pozner, Evrei v obshchei shkole, 97-122.

${ }^{14}$ S.V. Pozner, Evrei v obshchei shkole, 13-34; M. Morgulis, "Iz moih vospominanii.", no. 2 , 1895 , p. $110-116$; no. $5 / 6,1896$, p. $177-181$; no. 6/7, 1897 , p. $65-84$. 
Theoretically standard seminary education presupposed six years of training, but very often the students who found difficulty to cope with final exams stayed for two years at the same grade. Seminary graduates could continue their education in theological academies, similarly Jewish seminary graduates could enter Rabbinic colleges. Christian and Jewish seminaries had many similarities not only in the form of organization and instruction, but also in problems with their students. Sometimes the process of education seemed endless, beginners and repeaters studied together at the same classroom ${ }^{15}$.

The language of education is not very important in the perspective of self-identity for the majority. Thus Russian elite in the times of Pushkin, for example, hardly or not at all spoke Russian, still their identity was not under question as it completely determined their position in the social hierarchy. The minorities in this respect could be subdivided into those that physically belong to the state by having some land as property or those who have neither property nor roots. For landless minorities, such as the Jewish minority, the choice of the language became twice as strong as a marker of one's self-identity.

\section{Russian Jews at the end of the $19^{\text {th }}$ century: the time of choices}

By the turns of the $19^{\text {th }}$ century, over one million Jews lived within the borders of the Russian empire. That was two and a half times as many as the number of Jews in the Austro-Hungarian empire and five times more than the Jewish population of Prussia. That huge mass of the Jewish population was concentrated on a relatively small territory known as the Pale of Settlement. In the late $19^{\text {th }}$ century major changes in the social structure of the Jewish society took place.

It was the time of taking decisions: to remain inside the community, to keep it as closed as possible against the outer world (the tradition that preserved the Jews as people during the centuries of their life in Europe and thus as such extremely valuable from the point of view of preserving national identity) or to get integrated with the world outside the community. The first attitude, together with the pogroms, of course, later made the Jewish people start their mass migration from the Russian empire. The second attitude gave birth to the new, double identity. A new class, a class of educated people, the Jewish intellectuals, appeared. It was the group of people that began to publish Jewish periodicals in Russian. Alexander II, the reformer, abolished the restrictions imposed by his predecessors

${ }^{15}$ L.O. Pasternak, Zapisi raznyh let (Moscow: Sovetskii khudozhnik Publ., 1975), 67-119; N.G. Pomyalovskii, Ocherki bursy (Moscow: Prospekt Publ., 2014), 10-49. 
on the Jewish community. The Jews felt that they were capable of taking rightful place among the other ethnic and national groups of the Russian empire. They tried to break down the hostility and the prejudice that existed between the Jewish and non-Jewish societies. Russian language and use of literature and periodical press became a powerful tool in that communication between the representatives of Jewish and non-Jewish worlds ${ }^{16}$. The phenomenon of specifically Jewish media dismissed the idea of complete assimilation, although many of those periodicals were founded by their editors in the perspective of the basic idea of assimilation. Thus, the Russian-language Voskhod, for example, issued in Saint Petersburg in 1881-1906, had a circulation of 5,000 copies and its influence on the Jewish and non-Jewish reading public could hardly be underestimated. It should be noted that practically for all the authors of those publications, the Russian language was not the mother tongue, but nonetheless, it was chosen by the authors as the language of communication with the reader. At the same time the publications were clearly Jewish, the fact was always mentioned in the journals subtitles. The mother tongue of the authors and editors of Jewish periodicals in Russian was Yiddish. But despite the fact that in the late $19^{\text {th }}$ century Russia there were several periodicals in Yiddish, those authors had chosen Russian for their creative activity. That phenomenon was quite unique in terms of identity of the Jews in Russia ${ }^{17}$.

The end of the $19^{\text {th }}$ - the early $20^{\text {th }}$ centuries was characterized by the mass exodus of Jewish youth from the traditional Jewish settlements (shtetl) of the Pale of Settlement. This process contributed to the emergence of a new class of Jewish intellectuals, but as well changed the status of the Jewish proletariat, who became integrated into the social and political life of the Russian empire. Russian authorities and personally Russian tsar Alexander III were not interested in speeding up the process of Jewish integration. Temporary Provisions of 1887 defined the percentage norm for the Jewish population that could not exceed ten percent within the total population of the Pale of Settlement, five percent beyond the Pale and three percent in both capital cities. According to the population census of 1897 imperial subjects of Jewish religion comprised 5110548 persons or 4,03 percent of the general population. But in the Western provinces of the empire, Jews comprised 50 percent of the city dwellings of Lithuania and Byelorussia and 30 percent in Ukraine. Only 1,4 percent of them considered Russian language as native, 24,6 percent could express themselves in Russian and 97,9 percent spoke Yiddish ${ }^{18}$.

${ }^{16}$ Samuil Marshak, V nachale zhizni: stranitsy vospominanii, 196-208; U.G. Ivask, Evreiskaia pechat'v Rossii, 4-32.

${ }^{17}$ Y. Slutsky, Ha-'Itonut ha-Yehudit-Rusit ba-me'ah ha-tesha-esreh, 120-136.

${ }^{18}$ Yuliy I. Gessen, Istoriâ Evreiskogo naroda v Rossii, 21-34; B. Brutzkus, Statistika evreiiskago naseleniia: raspredielenie po territorii, demograficheskie i kul'turnye priznaki evreiskago naseleniia po dannym perepisi 1897 g. (St. Peterburg: Sever Print Hous, 1909). 


\section{Conclusions}

Thus the present article emphasizes the most important consequence of the historical situation at the end of the $19^{\text {th }}$ - the early $20^{\text {th }}$ centuries in relation to the Jewish minority, was the existence of three definite possibilities related to self-identity and language choice. The first possibility was complete assimilation of those people who were the children of the Jewish Russian speaking intelligentsia (doctors, lawyers, teachers, engineers, painters, musicians, etc.). The choice of partial assimilation of the Russian speaking students from orthodox Jewish families from the Pale of Settlement was the second possibility. The last choice or rather a decision to keep the tradition, was to stay within the frames of the traditional Jewish communities with a minimal contact with the surrounding population; in this case the knowledge of the Russian language as a language of communication was simply irrelevant.

The second group as the one that represents the transitional status of double self-identity is especially interesting: on the one hand, the desire to keep the Jewish roots takes place while on the other hand, the choice of a new language as a language of social communication and the tool of self-expression and creative activity could be clearly detected, the one that later allows equal with majority members possibilities to participate in the life of the whole country.

The frames of the present article are limited in space, but it presents a statement of a broader and more comprehensive research. Fate and integration, choices of the representatives of the group of people known as transition generation of Jews make it an extremely interesting subject for further academic research and analysis based on interdisciplinary approach of history and socio-linguistics.

\section{REFERENCES}

Aronson, I.M. "Russian Commissions on the Jewish Question in the 1880's." East European Quarterly 14, no. 1 (1980): 59-74.

Brushtein, A. Doroga uhodit vdal'. Moscow: Detguz Publ., 1956 (in Russian).

Brutzkus, B. Statistika evreiiskago naseleniia: raspredielenie po territorii, demograficheskie i kul'turnye priznaki evreiskago naseleniia po dannym perepisi $1897 \mathrm{~g}$. St. Peterburg: Sever Print Hous, 1909 (in Russian).

Dubnov, S.M. Kniga zhizni. Vospominaniia i razmyshleniia: materialy dlya istorii moego vremeni. Moscow: Eveiskiy universitet Publ., 1998 (in Russian).

Noveishaiia istoriia evreiskogo naroda. 1789-1881. Moscow; Ierusalim: Mosty kultury, and Gershaim Publ., 2002 (in Russian).

Fraenkel, Josef. The Jewish Press of the World. London: Cultural Department of the World Jewish Congress, 1956. 
Gel’fond, M.M. “Tvorcheskaiia istoriia avtobiograficheskoi trilogii A.Ya. Brushtein 'Doroga ukhodit vdal'." Novyi Filologicheskii Vestnik 28, no. 1 (2014): 81-90 (in Russian).

Gessen, Yuliy I. “Popytka emansipatsii evreev v Rossii.” Perezhitoe, no. 1 (1990): 144-163 (in Russian).

Istoria Evreiskogo naroda v Rossii. 2 vols. Leningrad: Printing house K.-O. Leningrad Gubprofso Council, 1925-1927 (in Russian).

Gradovskii, N.D. Otnoshenie $k$ evreyam v devnei i sovremennoi Rusi: Motivy istoriko-nacional'nye. S tochki zreniia russko-pravoslavnoi. Part 1. St. Petersburg: [S.n.], 1891 (in Russian).

Grets, H. Ot nachala Mendel 'sonovskoi epohi do noveishego vremeni (1750-1848). Vol. 12 of Istoriia evreev ot drevneishih vremen do nastoyashchego. Odessa: Print Hous of Sherman, 1900 (in Russian).

Grossman, Leonid. Ispoved'odnogo evreiia. Moscow; Leningrad: Svetoch Press, 1924 (in Russian).

Gumilev, Leonid N. Otkrytie Khazarii. Moscow: AST Publ., 2014 (in Russian).

Harcave, S.S. "The Jewish question in the first Russian Duma." Jewish Social Studies 6 (1944): 55-176.

Ivask, U.G. Evreiskaia pechat'v Rossii. Materialy dlya istorii evreiskoi zhurnalistiki. Issue 1. Tallin: [S.n.], 1935 (in Russian).

Kantor, R.M. "Razgrom evreiskoi intelligentsia.” Evreiskaia letopis, no. 2 (1924): 87-95 (in Russian).

Karasik, V. Evreiskaia pressa na russkom yazyke: bibliograficheskii spravochnik. Moscow: N.I. Krotov Publ., 1992 (in Russian).

Kassil, Lev A. Konduit i Shvambraniia. Moscow: Detskaiia literature Publ., 1960 (in Russian).

Karamzin, Nikolay M. Pis'ma russkogo puteshestvennika. Moscow: Pravda Publ., 1980.

Klier, John Doyle. Russia gathers her Jews: the origins of the "Jewish question" in Russia, 1772-1825. Dekalb: Northern Illinois University Press, 2011.

"The Ambiguous Legal Status of Russian Jewry in the Reign of Catherine II." Slavic Review 35, no. 3 (1976): 504-517.

Krutikov, M. "Pushkin v Vil'ne: Russkaiya Literatura i Evreiskaiya Intelligentsiya.” In Leo Philologiae. 128-163. Moscow: [S.n.], 2016 (in Russian).

Levanda, L.O. Tipy i siluyety: iz vospominanii zhkol'nika kontsa 40-h godov. St. Petersburg: Voshod Publ., 1881 (in Russian).

Lotman, Yuriy M. Struktura khudozhestvennogo teksta. Semioticheskie issledovaniia po teorii iskusstva. Moscow: Iskusstvo Publ., 1970 (in Russian).

Lowenstein, S.M. "Governmental Jewish policies in early nineteenth century Germany and Russia: A comparison.” Jewish Social Studies 46, no. 3/4, (1984): 303-320.

Marshak, Samuil. V nachale zhizni: stranitsy vospominanii. Moscow: Sovetskii pisatel' Publ., 1961 (in Russian).

Mordovtsev, D.L. Irod: istpricheskii roman. Moscow: P.P. Soikin Publ., 1914.

— Vol. 1 of Polnoe sobranie istoricheskih romanov, povestei rasskazov. S kritikobiograficheskim ocherkom. Moscow: [S.n.], 1902 (in Russian).

Morgulis, M. "Iz moih vospominanii." Voskhod, no. 2, 1895, p. 110-116; no. 5/6, 1896, p. 177-181; no. 6/7, 1897, p. 65-84 (in Russian). 
Orbach, A. New Voices of Russian Jewry: a study of the Russia-Jewish press of Odessa in the era of the Great reforms, 1860-1871. Leiden: Brill, 1980.

Orshanski, I.G. Evrei v Rossii: ocherki ekonomicheskogo i obshchestvennogo byta russkikh evreev. St. Petersburg: Print Hous of Bakst, 1877 (in Russian).

Pasternak, L.O. Zapisi raznyh let. Moscow: Sovetskii khudozhnik Publ., 1975 (in Russian).

Perlmann, M. "Notes on 'Rassvet' 1860-61." Proceedings of the American Academy for Jewish Research, no. 33 (1965): 21-50.

Pipes, Richard. "Catherine II and the Jews: The origins of the pale of settlement." East European Jewish Affairs 5, no. 2 (1975): 3-20.

Pomyalovskii, N.G. Ocherki bursy. Moscow: Prospekt Publ., 2014 (in Russian).

Pozner, S.V. Evrei v obshchei shkole: $k$ istorii zakonodatel'stva i pravitel'stvennoi politiki v oblasti evereiskago voprosa. St. Peterburg: Razum Publ., 1914 (in Russian).

Slutsky, Y. Ha- 'Itonut ha-Yehudit-Rusit ba-me'ah ha-tesha-esreh [Jewish Russian-language press in the $19^{\text {th }}$ century]. Jerusalem: Bialik institute, 1970 (in Hebrew).

Springer, A. "Gavriil Derzhavin's Jewish Reform Project of 1800.” Canadian-American Slavic Studies 10, no. 1 (1976): 1-23.

(C) Alla Meyerovich, Irena Vladimirsky, 2018

Submitted: 16 December 2017

For citation: Meyerovich, Alla, and Vladimirsky, Irena. "In search of self-identity: jews in the context of the russian culture." RUDN Journal of Russian History 17, no. 2 (2018): 234-247. DOI: 10.22363/2312-8674-2018-17-2-234-247

\title{
В ПОИСКАХ САМОИДЕНТИЧНОСТИ: ЕВРЕИ В КОНТЕКСТЕ РОССИЙСКОЙ КУЛЬТУРЫ
}

\section{А. Меерович, И. Владимирски}

\author{
Академический колледж Ахва \\ 79800 Израиль, г. Беэр-Тувия, Шикмим РОВ \\ irena@achva.ac.il
}

Данное исследование затрагивает вопросы формирования культурной и социальной самоидентификации национального меньшинства, существующего в рамках многонационального общества, а также формирования и функционирования государства как конгломерата разнородных национальных составляющих. Предмет настоящего исследования является актуальным в свете тех социальных процессов, с которыми сталкиваются в настоящее время страны Европы, а именно наличие в них крупных групп мигрантов и поиски путей их наилучшей ассимиляции в культурной, 
политической и социальной жизни общества. Национальные меньшинства, а именно характеризующий их привычный им образ жизни, язык, на котором они говорят, и система образования, в которую вовлечены их дети, с неизбежностью отражают превалирующие общественные тенденции, наличие целенаправленной разработанной официальной политики, а также наличие или отсутствие в обществе предрассудков и стереотипов восприятия данного национального меньшинства большинством общества. Авторы рассматривают поиск возможных путей интеграции и адаптации в общество различных национальных групп, а также формирование исторических и социальных условий, необходимых для выработки механизмов их интеграции. Выбор в пользу интеграции означает выбор и принятие новой культуры, ее языкового выражения и традиций, более глубокого понимания ее религиозных и этнических составляющих, без восприятия которых невозможно стать ее частью. В качестве примера анализируется история евреев России, включая особенности их религиозной жизни, особенностей системы их образования и использования языка как средства общения внутри общины и вне ее. Мемуары, дневники и воспоминания, как текстуальное выражение самоидентификации и самовыражения, в данном контексте являются наиболее ценным пластом источников, не получивших заслуживающего им внимания в научной литературе. Анализ путей адаптации национальных меньшинств может иметь универсальный характер и быть востребованным при формировании путей интеграции различных национальных меньшинств в единое общественное пространство.

Ключевые слова: евреи Российской империи, национальные меньшинства, многонациональное государство, национальная политика, самоидентификация

( ) Владимирски И., Меерович А., 2018

Рукопись поступила: 16 декабря 2017 г.

Для цитирования: Владимирски И., Меерович А. В поисках самоидентичности: евреи в контексте российской культуры // Вестник Российского университета дружбы народов. Серия: История России. 2018. Том 17. № 2. С. 234-247. DOI: 10.22363/2312-8674-2018-17-2-234-247 